\title{
Commentary
}

\section{Will coronavirus cause a big city exodus?}

What does the pandemic mean for the future of cities? We've seen predictions that COVID-19 is an 'extinction-level event' for expensive, commuter-driven megacities. We've also seen confidence: if the 'death of distance' didn't finish off big cities in the 1980s, why should this time be different?

These debates are bound up - in the UK and US, at least - with worries about empty city centres and working from home. At the time of writing, a majority of UK workers is commuting at least once a week (Figure 1, left). But city centre footfall - especially in the biggest places remains well down (Figure 1, right). And within big cities like London, footfall is shifting from cores to suburbs (Anderson, Hesketh et al. 2020).
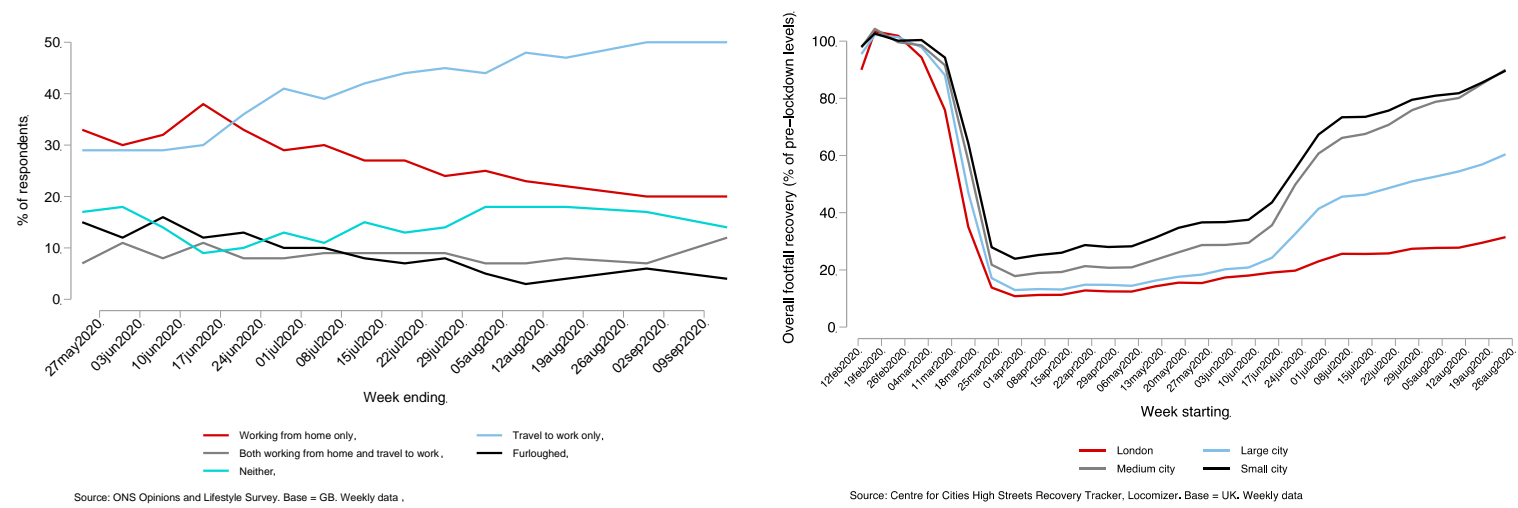

Figure 1. Left: Where are people working? Right: Footfall by city size.

Is this the beginning of the end for big cities? Academics have been quick to make predictions (Batty 2020, Couclelis 2020, Florida, Rodríguez-Pose et al. 2020, Kellerman 2020, Kleinman 2020). How should we assess the possibilities? A key uncertainty is how working from home affects productivity and innovation. A second is how we exit the pandemic. Exploring these issues helps us understand how big cities could now evolve. 


\section{1/ Remote possibilities}

Home working is increasingly feasible for many activities, including complex tasks requiring interaction (Clancy 2020). So why isn't it more common? One barrier is practicality. In most countries, the nature of the work - the 'task content' - means only a minority of jobs can be done from home - around 44\% in the UK (Dingel and Neiman 2020). Another barrier is inertia. Pre-pandemic, only $27 \%$ of UK workers had ever worked from home: a big gap (Office for National Statistics 2020). This gap has now closed: in a recent survey regular remote working had risen from $6 \%$ pre-pandemic to $43 \%$ by the end of June (Felstead and Reuschke 2020). That share will be higher in big cities.

As Clancy notes, even if remote working is not be as effective as face to face, firms may tradeoff less effective working practices for cost savings. The effect on productivity of the current shift is unknown. Newly-remote urban office workers work longer days, have more, but shorter, meetings and do more email (DeFilippis, Impink et al. 2020). While $29 \%$ of workers in Felstead and Reuschke's survey report higher output, 30\% say it had fallen.

We also lack robust pre-pandemic evidence. In specific cases - patent examining or call centres (Bloom, Liang et al. 2014, Choudhury, Foroughi et al. 2020) - shifting to remote working increased productivity. This tells us how existing teams adjust but says little about long term change. Those dynamics matter. Physically co-located workers - in workplaces, but also in incubators, accelerators and science parks - can learn more easily from each other, and develop and test new ideas (Madaleno, Nathan et al. 2018). These effects extend beyond the firm. Physical proximity in cities increases innovation, and this link remains strong, even as remote working tools have improved and travel costs have fallen (Duranton and Puga 2020). Dense urban areas are good at generating unconventional ideas (Berkes and Gaetani 2019) including through serendipitous interaction (Atkin, Chen et al. 2019). Even as new ideas diffuse, their birthplace retains disproportionate job shares in related activities (Bloom, Hassan et al. 2020). Learning is especially important for younger workers, who experience bigger wage gains when moving to urban cores (De La Roca and Puga 2017).

This raises the question of the private versus the social benefits of proximity. Even if shifting to home working makes individual firms more productive, cities could still lose the collective benefits of between-firm and worker interaction. Of course, mass remote workarounds for face 
to face may emerge (Page 2020). And constraints on face-to-face interaction can also alter the direction of innovation, in ways that might bring benefits (Andrews 2019). But these latter possibilities are highly speculative.

Firms will continue to experiment with ways of reorganising office work in the coming months. The longer the period of forced experiment, the more firms and their workers can figure out what works for them. This is one of many reasons why the length of the pandemic will matter.

\section{2/ Early exit}

An effective vaccine available from mid-2021 will mean a rapid end to the disruptions caused by lockdowns and social distancing. Unfortunately, temporary shocks - such as lockdown could have permanent scarring effects. The resilience literature suggests that richer regions, with more educated workforces, bounce back faster from recessions.

We should not assume a rapid return to pre-COVID norms. The pandemic may change longerterm behaviour - even if we exit early. Expectations about the likelihood of future pandemics may change, and that could shift preferences for big city living. The forced experiment of mass remote working could also act as a collective nudge. If this overcomes organisational inertia, working from home could permanently increase. These shifts, and others, are more likely if exit from the pandemic happens later.

\section{3/ Exit later}

What if a vaccine is two to three years away or - rather less likely - that COVID-19 becomes less infectious, or herd immunity emerges? This prolongs forced experimentation and moves us further from old norms.

If working from home does become an effective substitute for face-to-face interaction - and this is debatable - then it could increase the spatial footprint of more dynamic firms and cities as commuting does, but at lower economic, social and environmental costs. If this vision of workers in rural idylls dialling into high-paying, big city jobs sounds familiar, that's because it is: mass telecommuting, first promised decades ago, will have arrived.

One challenge to this rosy outlook is greater offshoring: if a task can be done anywhere, why not outside the UK? A second challenge is that profound reductions in transport and 
telecommunication costs generate further shifts in geographies of people and jobs, as changes in location preferences work through the urban system.

For home-working households, less commuting weakens the link between residential and work location. This means non-work considerations can play a bigger role in choosing where to live. In the UK, housing shortages and unresponsive supply make large population adjustments unfeasible. Instead, any significant drop in demand for big cities will produce higher house prices in desirable non-urban locations. Higher-paid jobs are more amenable to remote working, reinforcing these price effects. A similar story could play out within cities, with wealthier households moving to desirable suburbs. These shifts will reinforce spatial segregation, rather than 'levelling up'.

Wealthy households moving to the suburbs also increase demand for high-end shops, restaurants and gyms in those neighbourhoods. Will we see one-for-one shifts of activity from central cities to suburbs? This will depend on the extent to which households substitute home production, local or online purchases for the services they used to consume while at work. Many workers may make their own lunch when working from home Some shopping will shift to local businesses but it will also move online. Lockdown has seen many households substitute online shopping for physical retail (Relihan, Ward Jr. et al. 2020). Offsetting this is reduced expenditure on commuting and office clothing; against that, there is higher spending on office equipment and energy at home.

What about office work? A shift to home working lowers demand for office space and even as firms hold onto offices, many are already renegotiating or withholding rents. But companies are also experimenting, reorganising roles and workflows. One decision for firms is what tasks need to be done in the office, under social distancing if required. Another decision is when these tasks will be done - city traders who need fast, bespoke internet connections may need to be always-in, for example. Companies will need to figure out the impacts of home versus office working, and change management practices around this.

All this makes it hard to predict the future of urban office markets. We may see a lot more fulltime remote working, or more mixed patterns ('in five days in ten'). In the former case, total demand for office space will be lower. In the latter, total demand may be the same or higher. 
US firms surveyed in June predicted zero change in future demand for space (Altig, Barrero et al. 2020).

The wider geographical affects are also hard to predict. Falling transaction costs could lead to more concentration, with front office activities in city centres while 'back office' activities move to the suburbs. Functional specialisation could see headquarters increasingly concentrated in bigger cities, while smaller cities specialise in production.

\section{4/ No exit}

In the absence of an effective vaccine, declining infectiousness or herd immunity, Covid-19 will stay endemic, and will need to be managed through large-scale testing, track and trace and, if that fails, local lockdowns (Aleta, Martín-Corral et al. 2020). Where would this leave big cities?

One key question is whether big cities are more vulnerable to Covid-19, or future pandemics. Big cities have long been hard hit by disease but evidence on Covid-19 is limited. Contacttracing studies highlight how prolonged exposure in crowded, enclosed environments and events spreads the virus (Cevik, Marcus et al. 2020). Yet this doesn't mean that size, density or connectivity makes big cities inherently riskier.

In the UK and elsewhere, the biggest, densest cities were hit earlier. But allowing for timing, there may be no link between Covid-19 death rates and density (Carozzi, Provenzano et al. 2020). Other factors may offset the proximity disadvantage of big cities: younger than average populations, for example, and more residents who can reduce exposure by changing behaviour. If these findings generalise, economic, physical or demographic characteristics - reliance on public transport, crowded housing, physically and economically exposed work in frontline services, and concentrations of vulnerable groups - may better explain the spread of Covid-19. While these are features of many big cities, especially in more deprived neighbourhoods, they are also characteristics of poorer small cities and towns - where coronavirus cases are now high.

A radical shift in economic geography becomes more likely as the time to exit increases. A long crisis could alter beliefs about the likelihood of future pandemics, thus changing behaviour. Slow exit also allows further development of remote working practices and 
technologies. Diffusion lags can be lengthy: two decades passed before factories took full advantage of electrification, for example (David 1990). Large-scale shocks can also lead to permanent shifts - between 'multiple equilibria' - even if underlying fundamentals don't change. The benefits of co-location reduce when everyone is working from home. This reduces the individual benefits of a return to the office, even if there would be collective benefits from doing so.

'No exit' could also lead to other, long-term transformations. For example, for older households, more vulnerable to the disease, the benefits of home working will increase, while the amenity benefits of cities will weaken. As the young are less vulnerable, the demography of city centres could get even younger, while older households move to the suburbs or out of cities entirely.

Other adjustments will be needed. For example, can cities that rely on public transport find innovative commuting arrangements that manage congestion and allow employment to remain concentrated in the city centre (Hidalgo 2020)? How will they manage this given falling tax revenues, if demand for office space falls and takes some local services with it?

\section{5/ Conclusions}

The virus has already altered patterns of working, shopping and social interaction: the question is whether - and how - these continue.

Time to exit will shape big city futures. National differences will also matter. In countries with effective public health responses, change will be voluntary: as public confidence returns, firms and households can try out new ways of organising life and work (Parnell 2020). By contrast, in countries where the virus response is poor, forced adaptation will continue with all the difficulties that entails.

There will be other globalised pandemics. And cities still need to address larger, pre-existing challenges: most obviously, climate change. The way in which cities adapt to the current crisis, and the lessons learned for other challenges, may be as important as the novel coronavirus itself. 


\section{Max Nathan}

University College London \& Centre for Economic Performance. Corresponding author. max.nathan@ucl.ac.uk

\section{Henry Overman}

London School of Economics and Political Science \& Centre for Economic Performance h.g.overman@1se.ac.uk

An earlier version of this piece was published on the UKRI Economics Observatory.

\section{References}

Aleta, A., D. Martín-Corral, A. Pastore y Piontti, M. Ajelli, M. Litvinova, M. Chinazzi, N. E. Dean, M. E. Halloran, I. M. Longini Jr, S. Merler, A. Pentland, A. Vespignani, E. Moro and Y. Moreno (2020). "Modelling the impact of testing, contact tracing and household quarantine on second waves of COVID19." Nature Human Behaviour.

Altig, D., J. M. Barrero, N. Bloom, S. J. Davis, B. H. Meyer and N. Parker (2020). "Surveying Business Uncertainty." National Bureau of Economic Research Working Paper Series No. 25956.

Anderson, D., R. Hesketh, M. Kleinman and J. Portes (2020). A Global City in a Global Pandemic: Assessing the Ongoing Impact of COVID Induced Trends on London's Economic Sectors. GLO Discussion Paper Series 608. London, Global Labor Organization (GLO).

Andrews, M. (2019). Bar Talk: Informal Social Interactions, Alcohol Prohibition, and Invention. SSRN Working Paper 3849466.

Atkin, D., K. Chen and A. Popov (2019). The returns to face-to-face interactions: Knowledge spillovers in Silicon Valley. Mimeo.

Batty, M. (2020). "The Coronavirus crisis: What will the post-pandemic city look like?" Environment and Planning B 47(4): 547-552.

Berkes, E. and R. Gaetani (2019). The Geography of Unconventional Innovation. Rotman School of Management Working Paper No. 3423143, Available at SSRN: https://ssrn.com/abstract $=3423143$ or http://dx.doi.org/10.2139/ssrn.3423143

Bloom, N., T. A. Hassan, A. Kalyani, J. Lerner and A. Tahoun (2020). The Geography of New Technologies. INET Working Paper 126.

Bloom, N., J. Liang, J. Roberts and Z. J. Ying (2014). "Does Working from Home Work? Evidence from a Chinese Experiment *." The Quarterly Journal of Economics 130(1): 165-218.

Carozzi, F., S. Provenzano and S. Roth (2020). Urban Density and COVID-19 IZA Discussion Paper 13440. Bonn, IZA. 
Cevik, M., J. Marcus, C. Buckee and T. Smith (2020). SARS-CoV-2 Transmission Dynamics Should Inform Policy. vailable at SSRN: https://ssrn.com/abstract=3692807 or http://dx.doi.org/10.2139/ssrn.3692807

Choudhury, P., C. Foroughi and B. Zepp Larson (2020). "Work-from-Anywhere: The Productivity Effects of Geographic Flexibility." Academy of Management Proceedings 2020(1): 21199.

Clancy, M. (2020). The Case for Remote Work. Economics Working Papers 20007. Iowa, Iowa State University.

Couclelis, H. (2020). "There will be no Post-COVID city." Environment and Planning B: Urban Analytics and City Science 47(7): 1121-1123.

David, P. A. (1990). "The Dynamo and the Computer: An Historical Perspective on the Modern Productivity Paradox." The American Economic Review 80(2): 355-361.

De La Roca, J. and D. Puga (2017). "Learning by Working in Big Cities." The Review of Economic Studies 84(1): 106-142.

DeFilippis, E., S. M. Impink, M. Singell, J. T. Polzer and R. Sadun (2020). Collaborating During Coronavirus: The Impact of COVID-19 on the Nature of Work. NBER Working Paper 27612. Cambridge, MA, NBER. No. 27612.

Dingel, J. I. and B. Neiman (2020). "How many jobs can be done at home?" Journal of Public Economics 189: 104235.

Duranton, G. and D. Puga (2020). "The Economics of Urban Density." Journal of Economic Perspectives.

Felstead, A. and D. Reuschke (2020). Homeworking in the UK: Before and During the 2020 Lockdown. WISERD Report. Cardiff Wales Institute of Social and Economic Research.

Florida, R., A. Rodríguez-Pose and M. Storper (2020). Cities in a Post-COVID world. Papers in Evolutionary Economic Geography \# 20.41. Utrecht, Utrecht University.

Hidalgo, C. A. (2020). "Trillion dollar streets." Environment and Planning B: Urban Analytics and City Science 47(7): 1133-1135.

Kellerman, A. (2020). "The post-Corona city: Virus imprints and precautions." Environment and Planning B: Urban Analytics and City Science 47(7): 1124-1127.

Kleinman, M. (2020). "Policy challenges for the post-pandemic city." Environment and Planning B: Urban Analytics and City Science 47(7): 1136-1139.

Madaleno, M., M. Nathan, H. Overman and S. Waights (2018). Incubators, Accelerators and Regional Economic Development CEP Discussion Paper No 1575. London, LSE.

Office for National Statistics (2020). "Coronavirus and homeworking in the UK labour market: 2019 " https://www.ons.gov.uk/employmentandlabourmarket/peopleinwork/employmentandemployeetypes/a rticles/coronavirusandhomeworkingintheuklabourmarket/2019.

Page, S. (2020). "The Coronavirus and Innovation." https://items.ssrc.org/covid-19-and-the-socialsciences/policy-models-in-pandemic/the-coronavirus-and-innovation/. 
Parnell, S. (2020). "The enabling conditions of post-pandemic city government." Environment and Planning B: Urban Analytics and City Science 47(7): 1143-1145.

Relihan, L. E., M. M. Ward Jr., C. W. Wheat and D. Farrell (2020). The early impact of COVID-19 on local commerce: Changes in spend across neighborhoods and online. CEP Occasional Paper 50. London, Centre for Economic Performance. 